\title{
RELIGION AND SOCIAL TRANSFORMATION: \\ GERMANY'S DEMOCRATIZATION AFTER 1945 - THE AMERICAN RE-EDUCATION PROGRAMME ${ }^{12}$
}

\author{
Heike Springhart \\ Institute of Systematic Theology and Dogmatics \\ University of Heidelberg
}

\begin{abstract}
Totalitarian political regimes in Germany and South Africa had a severely negative impact on the equal and shared human dignity of inhabitants of these countries - both on institutional and personal level. In this article the role of religion in contributing to the institutionalizing of the equal and extensive dignity of all is considered. The American reeducation programme after 1945 functions as a case study and provides perspectives for the continued role of religion in democracies.
\end{abstract}

Key Words: National Socialism, Re-Education, Social Transformation, Public Theology, Democracy

\section{Introduction}

In the early 1980s in the German Democratic Republic, young people were becoming more and more dissatisfied with the situation in their country. As small children, they went to state kindergartens, where they learned to play with military toys. As pupils, they experienced only being allowed to visit the gymnasium if they adhered to the requirements of the state. As young adults, they learned that they were not allowed to choose freely where they wanted to live, but that the state decided for them after their marriage. As intellectual persons, they knew that they were not allowed to express their opinions freely and publicly, especially if they were critical of the developments in their country. Those young people also suffered from air pollution and environmental problems due to the open cast mining of brown coal. Hence, young people, in various parts of the GDR, decided to form so-called 'grassroots action groups' (Basisgruppen). And they looked for places where they could meet. Of course, their private homes were not very private, because of the GDR's secret police, called the 'Stasi'.

So they found a home for their engagement under the roofs of the churches, or at least of some churches. Of course, there have been many discussions within the protestant churches, whether and how much of a political role the church and pastors played. At that time, a powerful minority of pastors were convinced by the idea of the civil rights movement. It was at the churches of these pastors that the young people found a place to meet. They had access to infrastructure such as telephones and printing-machines, and they found pastors who were open to their critical ideas. In Dresden and Leipzig, and later also in other places of the GDR, public prayers for peace were established. Through the

This essay is based on a lecture which was given on 6 November 2009 at Nelson Mandela Metropolitan University, Port Elizabeth, Stellenbosch University, University of the Western Cape and Potchefstroom University. I would like to express my deep thanks to Prof Piet Naudé for his help with this publication and for a very fruitful discourse.

2 Dedicated to Prof Dr Günter Thomas (Bochum/Germany) for his $50^{\text {th }}$ birthday. 
liturgical prayer of the church they were able to give their ideas publicity. In September and October 1989, people dared to demonstrate on the streets, not knowing whether they would be imprisoned or even shot. The decisive moment came when on 9 October 1989, in Leipzig, when 70000 people participated in a non-violent demonstration (Jankowski, 2009). The state was not able to stand up to this non-violent power of the people - and on 9 November 1989, the Berlin Wall was torn down. In 2009, in Germany we celebrated the $20^{\text {th }}$ anniversary of this grassroots-democratization of Germany called the 'Peaceful Revolution' (Friedliche Revolution).

The story of Germany's recent history illustrates crucial issues concerning the question of social change and democratization. There are also certain structural parallels to the situation of democratization after 1989 and re-education after World War II in Western Germany. I wish to look at the idea of how democracy was able prosper under the roofs of the churches, especially the protestant churches.

The question behind this discussion is: How can one describe the relationship between religion and social transformation, especially democratization? In order to generate some ideas I will present some of the results of the research I undertook for my systematictheological dissertation that aimed at answering that question (Springhart, 2008, 2007).

After 1989, there has been renewed interest in the contemporary history, church history as well as the secular history of Germany. One reason is that in the years after 1989, new archives were made available, thus allowing German historiography to broaden its perspective of a reunited Germany.

Coeval authors of reports about American democratization politics, especially those who themselves were protagonists of such politics, hold the view that democracy had been imposed on the Germans from the outside - and therefore it was doomed to failure (Knappen, 1947; Zink, 1947; Montgomery, 1957; Merrit, 1995). Contrary to this estimation, papers from the 1960s hold the view that Germany turned towards democracy without any influence from the occupation powers (Dahrendorf, 1965).

Since the 1990s, thanks to publications from the Munich 'Institute for contemporary history' (IfZ, Institut für Zeitgeschichte), it is known that 're-education' was a central term used in American-German interactions and their consequences for the development of a democratic Germany after 1945 (Henke, 1995; Weisz, 1994; Rosenzweig, 1998; Hentschke, 2001).

The first wave of publications that researched re-education were seen in the 1970s, when most of the Office of Military Government, United States (OMGUS) documents were put on microfilm in connection with a transatlantic research project of the IfZ and the National Archives in Washington, DC. ${ }^{3}$ Most of these works considered re-education to be a process of education and training. Therefore, they focused their survey on the pedagogic sector (Bungenstab, 1970; Lange-Quassowski, 1979; Tent, 1982; Braun, 2003). Karl-Heinz Füssl draws a line from pedagogic considerations to the significance of the church in American re-education politics. But he holds the view that it has not been possible to come to a real 'restart' in connection with the churches (Füssl, 1994).

Recent sociological works, especially those by Uta Gerhardt, present the reductionist considerations of re-education as a mere pedagogic programme and focus on the dynamics of the transformation process as characterized by re-education and democratization. By analysing the works of Harvard-sociologist Talcott Parsons, Gerhardt came to an under-

\footnotetext{
Please note the following sources and their abbreviations as used in this text: NA: National Archives Washington DC; IfZ: Institut für Zeitgeschichte; Wü: Archiv der Evangelischen Landeskirche Württemberg; and GLA: Generallandesarchiv.
} 
standing of the post-1945 change as 'controlled institutional change'. He also analysed the psychiatric conceptions of Richard Brickner, who held the view that democratization in post-national socialist Germany could happen by empowering the so-called 'clear areas' in society. Gerhardt's works offer an explanatory model that can be made fruitful in dealing with the problem of religion and re-education (Gerhardt, 1993; 1996).

New historical works consider the post-war period in Germany in terms of 'changes'. However, with the exception of Christoph Klessmann, they are not particularly interested in the significance of the churches and religion for the different transformation processes of the $20^{\text {th }}$ century (Rupieper, 1993; Jarausch, 2004; Winkler, 2004; Klessmann, 1991).

In the theological realm, the historical perspective focuses on developments within the church. Publications concerning the direction of the German churches after 1945 consider the occupation powers and their politics only as basic conditions under which the churches had to organize their work. Church historical publications focus on the post-war debates regarding the problem of 'Restoration or restart?', and on the problem of (collective) guilt and on the debates regarding the problem of the de-nazification of the church (Herbert, 1989; Vollnhals, 1989; Greschat, 2002). Hitherto, only a few works focus on the question of church politics in the American Military Government after 1945 (Boyens, 1979; Scheerer, 1986; Lingk, 1996).

The survey of research done so far in the field of re-education and religion shows that there has been a lack of consideration for the dynamics of the transformation process, and of the impulses expected from religion and the churches. My dissertation is an attempt to analyse and clarify the spiritual and social changes after 1945, to evaluate the significance of religion and churches in this process and to examine the potential which they yielded to that process.

Thus, historical and sociological research was brought into fruitful discourse with systematic theological perspectives thus widening the existing image of the church, as presented by current research. There are a number of perspectives and images of the church that can be observed in the face of our question. In terms of occupation politics, the church was considered to be a substitute for political institutions by the military government. Priests and pastors, for example, often were the first persons to serve as contact persons for military personnel instead of the mayor (McClaskey, 1951).

With respect to the challenging necessities after the war and with respect to a reorientation of the church on the basis of her experiences with and in National Socialism, the image of the church as an ecclesia reformanda has regained relevance. From a sociological perspective, the church is seen as an integral part of society, not existing opposite to society, but within society. In other words: the church is part of the world, living out of God's revelation and towards God's revelation.

As we will see later, one of the main goals of re-education was to implement methods of free discourse in order to shape a climate of tolerance and to enable people to consider heterogeneity and pluralism as an opportunity rather than as a threat. In this respect, the church is considered to be a space of communication for theological convictions and for struggling with questions of truth and certainty. ${ }^{4}$

$4 \quad$ As my study was a systematic-theological dissertation empirical limitations had to be considered. Hence, the study was restricted to the North of Wuerttemberg-Baden, which was occupied by the American forces. The main sources are documents from the Office of Military Government for Germany (OMGUS), especially record groups 260 (OMGUS/OMGWB), 226 (Office of Strategic Services, OSS) and 59 (State Department). 
I would like to point out a crucial difference between the changes in Germany after 1945 and 1989 and the changes in South Africa after the end of apartheid. In both German totalitarian states, there was a strong idea of unity. In Nazi-Germany there was the slogan: 'one nation, one empire, one leader' (ein Volk, ein Reich, ein Führer). And in the GDR the leading (and only) political Party was called the 'Socialist Unity Party of Germany' (Sozialistische Einheitspartei Deutschlands, SED). Those people whom the leading party thought did not fit in with that special unity were expelled from society or even killed. In Nazi Germany they had the idea of a special German, Aryan race. All people had to prove that their ancestors were Aryan, which meant in particular: not Jewish. Jews were not considered to be Germans with a different religion, but as people of a different race. The Nazis planned to eradicate the Jews and also those people who were mentally and physically sick, those who were homosexual and of course all those who were critical of the system, such as Dietrich Bonhoeffer. One of the main elements of Nazi ideology was that everyone who was to some extent 'different' was to be eradicated. Thus, millions of people were killed in the so-called concentration camps, the most prominent camps being Auschwitz and Bergen-Belsen.

So the challenge of transforming from a society of 'unity' into a democracy was to develop sensitivity and space for heterogenic and pluralistic forms of society, and the fact that there are different religions, mentalities and individuals living in it, everyone with his or her particular dignity.

Apartheid, on the other hand, was an ideology that dogmatized particularity and differences and built a system of segregation based on these differences. Hence, in overcoming apartheid, there is the challenge to live in a unified society that is sensitive to pluralism, but needs more fluent concepts of pluralism.

It needs to be mentioned that the churches that were part of American re-education politics in the area in Germany where my study took place were protestant ones. Therefore, in this study the word 'church' refers to protestant churches, and as the theological questions are ecclesiological ones, I think it makes sense to use the more general term.

\section{'Re-education'}

After World War II (1945) rapid and far-reaching changes took place in Germany, in both church and society. These changes were initiated by the re-education programme, especially from the American occupation powers. A transformation process aiming towards democracy began and within this democratization process, religion and the churches were expected to play a significant role.

The process of democratization in Germany after 1945 was largely experimental. The situation consisted of a complex conglomerate of trends and interdependencies, the dynamics of which were insightful, especially regarding the significance of religion in the role of social transformation.

'Re-education' was considered not only as a pedagogic programme aiming at education, but as an important part of the democratization process in the early post-war period (Tent, 1982; Gerhardt, 2003). The concept of re-education was based on a special form of psychiatric therapy that was used as a metaphor for the treatment of post-war Germany. In the context of the mental-health-movement in the 1930s, a method was developed that had its origins in a therapist-patient-pact in order to empower the healthy parts of the patient's personality. In 1943, it was the work of Richard Brickner entitled 'Is Germany Incurable?' that made a connection between this new therapeutic method and the question of the treatment of Germany after National Socialism (Brickner, 1943; 1945). 
It is important to keep in mind that the ideas of Brickner compared the structures of society with the paranoid structures of a person - not of the idea, that every German person had a paranoid personality (Brickner, 1942).

Within the socio-scientific debates that were initiated and shaped by Brickner's proposals, the idea of 'clear areas' as possible points of contact for democracy became a central pattern for Germany's post-war treatment. Hence, the notion of re-education became important, and was aimed at a transforming the basic patterns of behaviour and conviction of the people. Therefore, religion and churches were thought to be of central importance to such a process.

\section{Planning and Structure of Re-education}

From the beginning of the 1940s, there was a planning process and theological, sociological and socio-psychiatric perspectives helped shape conceptual considerations. Such conceptions were especially evident in the community of Germany expatriates in the United States, who raised the question of the existence of 'the other Germany' (Krohn, 1987; Baerwald, 1980). Paul Tillich, a systematic theologian and emigrant from Frankfurt/Main to New York, became well-known in these circles through a controversy between himself and the Jewish author Emil Ludwig that circled around this question (Tillich, 1972). From March 31, 1942 to May 9, 1944 Tillich was the host of weekly radio broadcasts addressed to 'my German friends' (Tillich, 1973). These were broadcasted by the 'Voice of America' (VoA), which was the German service of the Office of War Information (OWI). In his broadcasts, Tillich had a twofold intention: first, he wanted to support and inform his 'German friends', i.e. the groups opposed to the Nazis in Germany. Second, this is my thesis, Tillich's broadcasts were of a performative character. In broadcasting and addressing his speeches to that 'other Germany', he demonstrated to his American dialogue partners that oppositional circles did exist. Of special interest is the fact that Tillich was chairman of the 'Council for a Democratic Germany' (Springart, 2008; Liebner, 2001).

As already mentioned, it was the socio-psychiatric approach of Richard Brickner that brought the pattern of empowering and encouraging 'clear areas' into the debate. This pattern essentially characterized the re-education process (Gerhardt, 2000).

Harvard sociologist Talcott Parsons considered controlled institutional change to be a means of social change. In the 1930s, he analyzed the phenomenon of National Socialism from a sociological perspective in an effort to comprehend it, and determined how to overcome National Socialism (Gerhardt, 1993). Three aspects of his analyses are relevant with regard to his suggestions for re-education. Parsons considered the fundamental danger of National Socialism to be that it attacked the free institutions of a democratic society, especially academic liberty, liberal learning and the Christian churches and their universalistic religion (Parsons (1993); Gerhardt, 2005). Secondly, Parsons considered it to be essential in a free society that a form of religion be present in it - a religion that shaped society and served as a critical counterpart. The third aspect deals with the challenges of the rapid changes since the age of industrialization. This period of rapid transformation was considered to have had destabilizing effects, and became fertile ground for the growth of an authoritarian system that communicated certainty by favouring structures of particularity.

In order to overcome National Socialism, Parsons suggested the need for controlled institutional change. He considered social institutions to be of central significance for the development of mentalities. As a consequence, a change and transformation of mentalities could be reached through controlled institutional change. Three approaches are thought to shape this change: regressive control should avert a relapse into barbarianism by punish- 
ment of war criminals and by the reinvention of the separation of powers. Direct control worked through the prohibition of national socialist institutions and ideology in order to achieve democracy. In terms of religion, the third form of control was the most important: permissive control. It consisted of future-oriented, innovative politics that specifically promoted those social areas and institutions that could be considered 'clear areas' in the sense of Brickner's definitions. In his differentiated approach to the functions of religion within the social system, Parsons considered religion to be a stabilizing factor. Particularly in alienating phases of transformation, religion was thought to play a significant role from a sociological point of view.

Besides these conceptual considerations in socio-scientific discourses, there was also an institutional and personal framework for re-education. In the 1940s there were strategic and organizational plans in political planning. Training centres for occupation officers were established. On 11 May 1942, the School of Military Government at the University of Virginia in Charlottesville was opened with the intention to train officers for military government and civil affairs service with American armed forces in occupied territories abroad. The question of the possibility of soldiers taking over civilian tasks was broadly discussed (Holborn, 1973; Bungenstab, 1973).

During the occupation phase, a special branch for Education and Religious Affairs (ERA), existed within the American Office of Military Government of Germany (OMGUS). ${ }^{5}$ The goals of that branch and of re-education in general consisted of freedom of religion, prevention of National Socialism and militarism and cooperation with the churches. ${ }^{6}$ In its work, the ERA was based on a grassroots-approach, starting with the 'clear areas' according to Brickner. The underlying basic conviction consisted of the idea of democracy as a way of life rather than a government system. Democracy was regarded as the spirit of humanity - an almost civil religious notion. ${ }^{7}$

The activities of ERA were mostly focussed on actions that aimed to democratize society through a democratization of the structures of the church. These were complemented by outside incentives like consultation programmes by American experts, exchange programmes for students and teachers with the US, supplying of curricula and teaching materials through textbook and curriculum centres and the reintegration of the German churches into international organizations as well as the establishment of interdenominational cooperation as a means of overcoming National Socialist isolation.

One of the main roles of the church, in the eyes of the occupation power, was to be a source of moral and spiritual guidance (McClaskey, 1951). The church was expected to give ethical and moral orientation in order to help shape and stabilize society in its different subsystems. There was the hope that church and religion would have a positive impact on democracy.

The American view considered it of central significance that there was a differentiation between 'clerical' and 'secular' functions of the church $\left({ }^{8}\right.$ In order to avoid the violation of the principle of separation of church and state, for example, the consulting work through experts from the states was limited to the secular functions of the church, such as adminis-

Cf. NA, RG 260 OMGUS, 12/229-3/3. Zone handbook southwest through German basic handbook. Box 1298, Washington DC. (April 1944).

6 Cf. GLA, RG 260 OMGUS, 12/93-2/91, Karlsruhe: MGR, Revision of Title 8, Part 1. General. Section B. General Policies for Religious Affairs (22.09.1948), Paragraph 8-110.

Cf. Wü, D 1/205, 20. Memorandum: Der gegenwärtige Stand der Erziehung in Deutschland.

8 Cf. GLA, RG 260 OMGUS, 12/93-2/78, Karlsruhe: Memorandum concerning Clarification of Status of Dr Bodensieck and Bishop Muench. 
tration, questions concerning the church as an institution, and also the pedagogical work of the church at school and in youth work. In the realm of clerical functions, the churches were free and independent with regard to liturgy, confession and theology. The best way to illustrate the process of social transformation after 1945 is to investigate the concrete actions that took place at that time. Below are a few examples to demonstrate this.

\section{Re-education and Democratization in various Fields of the Church}

A very important field was the field of youth work and schools. Here re-education was considered to be a process of education and training. ${ }^{9}$ New methods, oriented towards free discourses were to be implemented in order to encourage an individual sense of responsibility. Furthermore, a goal of youth work and schools was to impart values that were able to instil certainty and ethical, cultural and religious orientation. In the realm of youth work, new structures were implemented which were oriented towards heterogeneity, pluralism and differentiation in order to empower an individual sense of responsibility (Springhart, 2008). In the realm of public schools, every child was to have the same right to education and training. The ERA-officers held the view that a future German society required people who had strict morals, and who lived a kind of 'practical Christianity. ${ }^{10}$ Hence, the church was responsible for the ecclesiastical fields of education and schools. A general principle of the work of ERA was the so-called 'indirect rule'. ${ }^{11}$ As a consequence, teachers and pastors were trained in new education methods in order to serve as purveyors of democratic methods and spirit. An essential part of ERA's activities at the schools was the school feeding programmes (Bungenstab, 1970; Füssl, 1994).

Similar goals can be observed in the work with institutions of adult education, especially the Protestant Academies. The Protestant Academies still exist today and they are institutions separate from academia such as universities. In these institutions interested adults of different professions can discuss theological issues and ask questions concerning their role as Christians in their particular profession (Olbrich, 2001). Since 1945, the work and role of the Protestant Academies in German society were considered a paradigm for the significance of religion in society. After their foundation in 1945, the basic concept of the Protestant Academies was to provide the freedom for spiritual discussions within the different professional guilds, such as teachers, physicians and lawyers (Keller, 1943; Treidel, 2001). ${ }^{12}$ Particularly through the work of the Academies the church became aware of being a space where democracy and democratic behaviour could be studied and learned. The Academies were places where the transformation process could be critiqued, and where students were trained to take individual responsibility in shaping the young democracy, through discussions and debates. The Protestant Academies - supported by financial and organizational aid from the US - thus became geographically identifiable as sources of moral and spiritual support. Hence, through the Protestant Academies there was an increasing sense of public responsibility on the part of the church.

9 General considerations can be found in: Wü, D 1/205, 20. Memorandum: Der gegenwärtige Stand der Erziehung in Deutschland, 42; cf. also Goedde (2003).

10 Cf. NA, RG 260 OMGUS, 12/86-1/24. Box 881, Folder 208.3 Records of the Education and Cultural Relations Division, Hq. Chief: Correspondence and related records (decimal file), 1945-49, Washington DC.

11 Cf. Supreme Headquarters, Allied Expeditionary Force. Handbook for Military Government in Germany prior to Defeat or Surrender, December, 1944, chapter III, 74.

12 The descriptions and plans of the Protestant Academies show similarities to the work of the National Christian Mission 1936/37 in the USA. There the gathering of people for evangelization was also oriented on their profession. 
In addition to the educational institutions, other fields of ecclesiastical work were considered to be significant in the transformation to democracy: Ecclesiastical women's work was especially challenged due to pragmatic necessities, as most of the men were abroad as prisoners of war or having lost their lives on the battlefront. ${ }^{13}$ Women had to take on responsibilities not only in daily life at home, but also in political life. Special courses were held to provide leadership skills for responsible women. ${ }^{14}$ It was intended that the new, democratic way of life would slowly become clear concerning the different roles of men and women in private and public life and how these were to be justified (or not justified). ${ }^{15}$

The fact that all human beings are created equal was only thought to be imposed successfully in the German thinking if this conviction was also applied to the dynamics encompassing the family unit. It was considered to be of central importance for a successful democracy that individuals, especially women, were ready to take on responsibility. This was new for the German society, for up until 1945, the work of women was primarily focused on their private households. To empower them to public responsibility was thus a revolutionary change (Zepp, 2007).

Another field of high importance for re-education politics was the diaconical work of protestant relief organizations (Evangelisches Hilfswerk) (Krimm, 1974). The success of democratization and re-education were thought to be dependent on whether the daily necessities of life were satisfied. A central principle was that it is only possible to win people over to new ideas and convictions if they are given responsibility, instead of simply being recipients of material, spiritual or educational help. For this reason, the German churches, especially their relief organizations, were given the task of distributing relief packages, such as CARE-packages to the people (Springhart, 2008). At least two effects were thus reached: people were motivated to access the services provided by the church and thus to make contact with the church, because there they could get help for their daily needs. The concept behind the CARE-organization was that international and inter-personal relationships were the basis on which reconciliation was built. Re-education was an idea of the occupation powers after the War, and it was considered to be of central importance that nobody should know this. This was achieved by allowing German institutions to distribute the relief packages. Although the material goods came from abroad, it was a project of selfhelp. Furthermore, part of the re-education concept was to ensure that the churches regained their public reputation and responsibility (Weyerer, 2001).

The churches were expected to communicate their moral and spiritual values, to the democratization process. Hence, the broadcasting and print media were to become new fields of action for the church. The communication of religious values as basic principles of a successful and stable democracy had to be managed more effectively by a professional use of mass media. ${ }^{16}$ To cope with this challenge, representatives of German churches were invited to take part in training programmes. Ecclesiastical news agencies were initiated in order to guarantee information that was independent from state agencies, in order to make it possible for the voice of the church to be heard in the secular media in a competent and informed way. The church as a 'clear area' was not expected to stay in a hermetic area,

Cf. IfZ, RG 260 OMGUS, 5/341-1/11-12, 4/4, Article: Women's Organizations and Social Action, 1, 1947.

4 Cf. GLA, RG 260 OMGUS, 12/93-2/81, Karlsruhe. Interdivisional Reorientation Committee Form for Reporting Cultural Exchange Projects for 1950. Project No. 22 (Evangelical).

15 Cf. Wü, D 1/205, 20. Memorandum: Der gegenwärtige Stand der Erziehung in Deutschland.

16 Cf. Wü, D1/272. Maier, WA 1947. Bericht und Anregungen über Religiöse Rundfunkübertragungen in Deutschland (Amerikanische Zone), 14.10.1947. 
where people had to make an effort to access it. Due to the consequences of the war, lots of people were just not able to reach a church, as there was no public transportation and many church buildings had been destroyed by bombing. ${ }^{17}$

Special attention was paid to the institutional points of contact between church and state that were considered important in the democratizing process. In the opinion of the American occupation authorities, there was the idea that the church's positive effect on a democracy could be fostered by entanglements, such as the state collecting taxes for the church, which is still the case in Germany today. ${ }^{18}$ Religious education at school was also considered to be a democracy-promoting entanglement.

In addition to supporting democratizing factors from inside Germany, democratization was also thought to be supported through outside incentives. It is important to keep in mind that with the different outside incentives the guiding principle was that indirect rule was based on the conviction that successful democratization could only be achieved from inside German society.

Special consultation programmes by American experts supported the different areas of ecclesiastical and pedagogical work. Visiting experts from the US came to Germany in order to discuss the new challenges, ${ }^{19}$ and so-called liaison representatives from American denominations visited the German churches to discuss the new challenges and to give them support. ${ }^{20}$ There was the hope that through contact with theologians and church representatives from abroad, the German churches would have the opportunity to dialogue and to widen their perspective (Kellermann, 1978).

\section{The Significance of Religion for Democratization: Conceptual Aspects ${ }^{21}$}

In terms of historical aspects, the churches were considered by American planning institutions as places of resistance against National Socialism. The American occupation authorities knew about the churches resistance in the years under National Socialism (1933-45) and how they showed particular strength in the struggle against the Nazis (Littell, 1960). Resistance against National Socialism was seen as having grown out of ecclesiastical roots and thus the church became a place of resistance. ${ }^{22}$ This was the main reason why the church was considered to be a 'clear area' from Brickner's perspective.

However, from an historical perspective, of course, the interpretation that the churches, especially the protestant church, was a place of resistance against National Socialism was not correct at all and the American view was perhaps too optimistic. However, a closer look at documents of the Office of Strategic Services (OSS) shows that there was a more differentiated perspective regarding the failure of the church. This was either due to the

17 Cf. Supreme Headquarters, Allied Forces G-5 Division. Technical Manual for Education and Religious Affairs, chap. 11, Military Government Germany, The Religious Press. February 1945; see also: Nahr (1981).

18 Cf. GLA, RG 260 OMGUS, 12/93-2/91, Karlsruhe. Report of the US Occupation of Germany, Religious Affairs Programme, 23.09.1947, 5: "The question of whether or not the traditional pattern of church-staterelations should continue to prevail in the future is a matter which has been left for the German people themselves to decide. US Military Government authorities have not considered it advisable to impose American ideas regarding separation of church and state upon the people of the US zone."

19 Cf. GLA, RG 260 OMGUS, 3/407-2/12, Karlsruhe. Quarterly Report, January-March 1947, Education \& Religious Affairs Division, p. 3.

20 Cf. GLA, RG 260 OMGUS, 12/93-2/78, Karlsruhe. Box 942, Folder: Church-Liaison Representatives. See also: Rupieper (1993, p. 353).

21 For a more detailed description cf. Springhart (2008).

22 Cf. Wü, D1/208, EE Turner (1945). Ein Abschiedswort an meine Freunde in der Bekennenden Kirche, 20.12.1945. 
conflict between National Socialism and the church not being clearly evident or that it was (mis-)interpreted as an inter-church conflict. Nonetheless representatives of resistance groups expected the church to be able to be that force in society that eradicates Nazism from hearts and heads. It is not the historical function as such, but the estimation that there is a kind of spiritual substance within the church that enhances resistant behaviour. Religion is considered to be a critical force opposite state and society. Its significance for the transformation process lies in that critical power. Religion and churches are considered to be areas that focus on the Divine that is radically differentiated from the world. At the same time religion and churches are part of this world and are - following Karl Barth's theses in his Tambach speech - incorporated in God's moving within the movements of the world (Barth, 1977).

There is also a political aspect, which focuses on the correlation between church and state. From a political as well as from a sociological perspective, the church was considered to be an institution within the social system. Following Talcott Parsons's theory, institutions are considered to be of central significance for the transformation of mentalities (Parsons, 1993). The individual person participates in different subsystems of society and as a consequence, transformation within one subsystem can develop a transforming influence on another subsystem through the individual. Within this process the political aspect is of a special significance. The specific role of religion was thought be a de-dramatization of the alienating process of transformation through specific proposals of meaning that could serve as an answer to the question of meaning. Thus religion could serve as a strategy of coping with transformation (Spotts, 1976). There was a twofold role of religion within the democratization process. On one hand religion was considered to be a system that supported and demanded transformation by widening peoples' perspectives, leading towards a special form of universalism, transcending national and ideological boundaries. On the other hand religion has a stabilizing effect on the individual in offering de-dramatizing proposals of meaning. As a consequence, religion helped avoid mechanisms of escaping pluralisation towards certainty where the latter might suggest totalitarian concepts of unity.

Furthermore, there is an ecclesiological aspect, which forms the basis of the perspective of religion for re-education. The military government had a special notion of the church, characterized by the differentiation between clerical and secular functions. In sociological terms, the church was characterized functionally, as it was described according to the functions that it fulfilled in and for society. The occupation powers considered the church to be the only social institution that survived National Socialism. Based on the principle of the separation of church and state, the military government, especially the ERA Branch, limited their cooperation and influence to the institutional aspects of the church and not the clerical functions, which were those areas that were related to the spiritual and religious functions of the church. Aspects concerning confessional questions, ordaining of pastors, the sacraments and preaching were independent from the military government.

In dealing with the question of the significance of religion in re-education, one observes an illuminating tension between the ecclesiological concept and the general expectations regarding the possibilities of spiritual and moral reconstruction. The church was granted nearly unlimited freedom on the level of secular functions, as well as on the level of clerical functions (McClaskey, 1951). In order to adequately comprehend the significance of religion in re-education, a complementary view is necessary. On the one hand, the military government interacted with the church on the institutional, or the secular level. However, on the other hand, it was in the realm of clerical functions from which decisive democratizing impulses were expected. 
These impulses are directly linked to ethics. In the light of ethics, it is clear that spirituality was a significant factor in the democratization process. The church was regarded as a source of moral and spiritual support. ${ }^{23}$ The church was considered necessary for the success of the democratization process and the church, as an institution of continuity, served as a place of stability forming the moral foundation of the developing democracy. Furthermore, the church was expected to represent and to communicate those spiritual and intellectual values that help shape a democratic society. I suggest that the church consists of two pillars in the democratizing process, namely: 'stabilizing continuity' on the one hand and 'transforming spirituality' on the other hand.

Stabilizing continuity revolves around the quest for new and orienting answers to the meaning of life and around the longing for spiritual sustenance, and was expected to gain importance after the collapse of the National Socialist regime. Values, based on principles of Christian life and faith, were expected to help achieve social stability in the years after 1945. The core notion was the need for 'responsibility' in order to bring about a set of moral values.

Transforming spirituality was a matter of content. For example, it was considered a major advantage of the church's youth work that the young people were able to identify with a matter that had a revolutionary ring to it. The church was seen as providing a challenge to the historical, cultural and social reality, with the core of its message: the radical challenge to the powers and forces of this world as viewed through the cross of Christ.

Furthermore, there were sociological and theological aspects. The sociological approach to re-education politics was shaped by considerations in the realm of the sociology of religion and by the fact that regularly there were public opinion surveys in order to act responsibly and according to real necessities (Merritt, 1995).

Religious pluralism was considered a challenge for the pluralism of democracy. Besides the fact that in $194596 \%$ of the German population belonged either to the Catholic or to the Protestant churches. In a document of 1948 called 'basic considerations' 24 there was the observation that religion is an ambivalent phenomenon in society, as it is both enriching as well as endangering. Being a moral and spiritual source, religion is enriching for the life of a society. However, as religion gives answers to the questions of ultimate concern, religiocultural diversity could also endanger society. The Christian religion was considered to have the potential to shape pluralism, because it incorporates in itself the tension of unity and difference, which has its source in the triune God. The orientation on difference and plurality opens spaces for shaping, for conversation and for common truth-seeking.

Based on this, religion was considered to be a means of coping with contingency in times of change (Knauth, 1946). Following Parsons' analysis of the emergence of National Socialism it was taken for granted that for a successful transformation it was necessary for a constructive exposure to uncertainty and fear caused by rapid changes. By shaping transformation and moreover by offering an interpretation of transformation in Christian terms,

23 Cf. GLA, RG 260 OMGUS, 12/93-2/91, Karlsruhe. MGR, Revision of Title 8, Part 1. General. Section B. General Policies for Religious Affairs, 22.09.1948, Paragraph 8-110: "Religious institutions are recognized as a significant element in the social structure of Germany and shall be given commensurate consideration in the programme of re-education and reorientation conducted for the building of a peaceful and democratic Germany. The values inherent in the moral and spiritual resources of the German people are recognized as essential to the realization of this programme. The development of these resources will be stimulated and encouraged."

24 Cf. GLA, RG 260 OMGUS, 12/93-2/91, Karlsruhe. Objectives Religious Affairs Branch (25.06.1948). Basic Considerations. 
the Christian religion helps bring about an attitude that comprehends contingency not primarily as endangering, but as transforming challenges. Thus, religion may help people to cope with contingency.

As the process of re-education aimed at transforming German society into a democracy, the relationship between Protestantism and democracy became of great importance (Knappen, 1947; Fischer, 1970). This was evident in the learning process within the German church, which was paradigmatic for the learning process in society. However, there was no traditional connection between Protestantism and democracy in Germany. Therefore, the majority of Protestantism and protestant theology at that time was oriented towards taking 'orders' and sceptical of democracy. But after 1945, every individual was able to participate in politics and influence every social subsystem, thus the protestant religion gained a twofold role: It was constitutively related to the community and thus created a sense of solidarity and consciousness of responsibility (Huber, 1990). And it was deeply rooted in the individual and strengthened his position as a person thinking critically and acting independently.

\section{Conclusion: Perspectives for Democracy Today}

It can be said that a stabilizing continuity, in the sense of a perpetuation of Christian traditions and values on one hand and transforming spirituality, in the sense of the Christian message revolving around critical and eschatological contexts on the other hand, were the two main points of importance regarding religion for re-education and democratization in Germany after 1945 .

Considering democracy today and the theological contributions that can be made to it, I would like to suggest that 'stabilizing continuity' and 'transforming spirituality' are the two key points that proceed beyond the historical situation of post-war Germany. That means in dogmatic terms that the church is not to be considered primarily in opposition (and opposite) to culture and society, but as a part of culture. Both the church and culture are created out of the Word of God and both are critiqued by the Word of God. Standing in midst of culture and society, the church sustains the brunt of this critique, based on the message of the cross and based on the revelation of the self-endangerment of the world at the cross.

Furthermore, this critique is possible only because the church lives out of the power of the resurrection and the realization of the victory over death in the resurrection. Based on this deliverance, the church is sent into the world to shape society. In that sense, the church does have a function in society - without being functionalized.

For a democracy, it is central that pluralism is considered to be enriching and not dangerous (Welker, 1995). But it is crucial that plurality does not mean that society is divided into particular subsystems, groups or even races or religions. Here, I would like to emphasise Parsons' theory again. He considered the different societal institutions to be of central importance for the shaping and changing of mentalities. Every individual belongs to different social institutions (e.g. university, protestant church, political groups, cultural groups etc.). For this to occur, the boundaries between those institutions and social subsystems are blurred.

If one considers religion as a strategy of coping in such a situation, it has the task to transform by keeping and communicating the consciousness of a plurality that does not divide society. In other words: individuals are different, but equal in dignity. Christian theology may offer concepts of universalism - that belongs to the stabilizing effects of continuity in the process of social transformation. However, it is important to differentiate 
between universalism and totalitarianism. Therefore, the second key point is important, which I called 'transforming spirituality'. It is based on the conviction that the foundation of church and society lies beyond both in God's creating power and that this is God's story. It is a living story and it becomes clear that the development of our societies is something that cannot be left apart from our theological thinking.

Let me end by telling another story of the weeks of change in 1989 in Eastern Germany. On that decisive Monday, on 9 October in Leipzig, the people were told not to go downtown to the prayers for peace, but stay at home. Normal people in the GDR had to work at their companies until $5 \mathrm{pm}$, but by $3 \mathrm{pm}$ almost every seat in the Nikolaikirche was occupied. When the pastor saw this he also realized that some of these people must be members of the secret police, the so-called 'Stasi'. Of course, there was no possibility - and he had no wish - to throw them out of the church, but he asked them to leave the places in the gallery clear for the members of the working population. By saying these words, he made it clear that he was aware of who was sitting in the church. But these Stasi people had to sit there and they stayed until the end of the prayer for peace. For most of them it was the first time they attended a service. Their notion that the congregants were 'enemies of the state' was proven wrong. In attending the prayer service in the Nikolaikirche they suddenly became one with the rest of the community, which they were trained to observe and arrest. In this prayer they had experienced something about the culture of discourse, respect and the spirit of transformation that is an expression of the politically connected hope that we as Christians talk about.

\section{BIBLIOGRAPHY}

Baerwald, F 1980. Zur politischen Tätigkeit deutscher Emigranten im Council for a Democratic Germany. Vierteljahreshefte für Zeitgeschichte, 28, 372-380.

Barth, K 1977. Der Christ in der Gesellschaft (1919). In J Moltmann (ed.), Anfänge der Dialektischen Theologie, Bd. 1 (ThB 17) (pp. 3-37). München: Kaiser.

Boyens, A 1979. Die Kirchenpolitik der amerikanischen Besatzungsmacht von 1944-1946. Ein vernachlässigtes Gebiet. In A Boyens, M Greschat, R von Thadden, P Pombeni, Kirchen in der Nachkriegszeit, (pp. 7-99). Göttingen: Vandenhoeck und Ruprecht..

Braun, B 2003. Umerziehung in der amerikanischen Besatzungszone. Die Schul- und Bildungspolitik in Württemberg-Baden von 1945-1949. Münster: LIT.

Brickner, R 1945. Germany after the War. Round Table 1945. American Journal of Orthopsychiatry, 15 (1945), 381-441.

Brickner, R 1943. Is Germany Incurable? New York: JB Lippincott.

Brickner, R 1942. The German cultural paranoid trend. American Journal of Orthopsychiatry, 12, 611-632.

Bungenstab, K-E 1973. Die Ausbildung der amerikanischen Offiziere für die Militärregierungen nach 1945. Jahrbuch für Amerikastudien, 18, 195-212.

Bungenstab, K-E 1970. Umerziehung zur Demokratie? Re-education-Politik im Bildungswesen der US-Zone 1945-1949. Düsseldorf: Bertelsmann.

Dahrendorf, R 1965. Gesellschaft und Demokratie in Deutschland. München: Piper \& Co. Verlag.

Fischer, HG 1970. Evangelische Kirche und Demokratie nach 1945. Ein Beitrag zum Problem der politischen Theologie. Historische Studien, 407. 
Füssl, K-H 1994. Die Umerziehung der Deutschen. Jugend und Schule unter den Siegermächten des Zweiten Weltkriegs 1945-1955. Paderborn: Schoeningh.

Gerhardt, U 2005. Soziologie der Stunde Null. Zur Gesellschaftskonzeption des amerikanischen Besatzungsregimes in Deutschland 1944-1945/1946. Frankfurt a. Main: Suhrkamp.

Gerhardt, U 2003. Das Reeducation-Programmem der USA. In H Erler, A Paucker, EL Ehrlich, (eds.), Gegen alle Vergeblichkeit. Jüdischer Widerstand gegen den Nationalsozialismus (pp. 407-431). Frankfurt a. Main: Campus-Verlag.

Gerhardt, U 2000. Re-Education als Demokratisierung der Gesellschaft Deutschlands durch das amerikanische Besatzungsregime. Ein historischer Bericht. Leviathan, 3, 355-385.

Gerhardt, U 1996. A Hidden Agenda of Recovery. The Psychiatric Conceptualization of Reeducation for Germany in the United States during World War II. German History, 14(3), 297-324.

Gerhardt, U 1993. Talcott Parsons on National Socialism. New York: Aldine de Gruyter.

GLA, RG 260 OMGUS, 3/407-2/12, Karlsruhe. Quarterly Report, January-March 1947, Education \& Religious Affairs Division.

GLA, RG 260 OMGUS, 12/93-2/78, Karlsruhe: Memorandum concerning Clarification of Status of Dr. Bodensieck and Bishop Muench.

GLA, RG 260 OMGUS, 12/93-2/78, Karlsruhe. Box 942, Folder: Church-Liaison Representatives. See also: Rupieper (1993, p. 353).

GLA, RG 260 OMGUS, 12/93-2/81, Karlsruhe. Interdivisional Reorientation Committee Form for Reporting Cultural Exchange Projects for 1950. Project No. 22 (Evangelical).

GLA, RG 260 OMGUS, 12/93-2/91, Karlsruhe: MGR, Revision of Title 8, Part 1. General. Section B. General Policies for Religious Affairs. 22.09.1948.

GLA, RG 260 OMGUS, 12/93-2/91, Karlsruhe. Report of the US Occupation of Germany, Religious Affairs Programme. 23.09.1947.

GLA, RG 260 OMGUS, 12/93-2/91, Karlsruhe. General Policies for Religious Affairs, MGR, Revision of Title 8, Part 1. General. Section B. 22.09.1948.

GLA, RG 260 OMGUS, 12/93-2/91, Karlsruhe. Objectives Religious Affairs BranchBasic Considerations. 25.06.1948.

Goedde, P 2003. GIs and Germans. Culture, gender, and foreign relations 1945-1949. New Haven: Yale University Press.

Greschat, M 2002. Die evangelische Christenheit und die deutsche Geschichte nach 1945. Stuttgart: Kohlhammer.

Henke, K-D 1995. Die amerikanische Besetzung Deutschlands. München: Oldenbourg.

Hentschke, F 2001. Demokratisierung als Ziel der amerikanischen Besatzungspolitik in Deutschland und Japan 1943-1947. Münster: LIT.

Herbert, K 1989. Kirche zwischen Aufbruch und Tradition. Entscheidungsjahre nach 1945. Stuttgart: Radius-Verlag.

Holborn, H 1947. American Military Government. Its Organization and Policies. Washington: Infantry Journal Press.

Huber, W 1990. Protestantismus und Demokratie. In W Huber (ed.), Protestanten in der Demokratie. Positionen und Profile im Nachkriegsdeutschland (pp. 11-36). München: Kaiser. 
IfZ, RG 260 OMGUS, 5/341-1/11-12, 4/4, Women's Organizations and Social Action, $1,1947$.

Jankowski, M 2009. Der Tag, der Deutschland veränderte. 9. Oktober 1989. Leipzig: Evangelische Verlagsanstalt.

Jarausch, K 2004. Die Umkehr. Deutsche Wandlungen 1945-1995. Bonn: Bundeszentrale für politische Bildung.

Keller, A 1943. Amerikanisches Christentum - Heute. Zollikon-Zürich: Evangelischer Verlag.

Kellermann, HJ 1978. Cultural relations as an instrument of US foreign policy. The Educational Exchange Programme between the United States and Germany 1945-1954. Washington DC: Government Printing Office.

Klessmann, C 1991. Die doppelte Staatsgründung. Deutsche Geschichte 1945-1955. Bonn: Bundeszentrale für politische Bildung.

Knappen, MM 1947. And call it peace. Chicago: University of Chicago Press.

Knappen, MM 1947. Allied military government policy and the religious affairs situation in Germany. Church History, 16(2), June, 92-103.

Knauth, P 1946. Germany in defeat. New York: Alfred A Knopf.

Krimm, H 1974. Beistand. Die Tätigkeit des Hilfswerks der Evangelischen Kirchen in Deutschland für Vertriebene und Flüchtlinge nach 1945. Stuttgart: Evangelisches Verlagswerk.

Krohn, C-D 1987. 'Let us be prepared to win the peace'. Nachkriegsplanungen emigrierter deutscher Sozialwissenschaftler an der New School for Social Research in New York. In T. Koebner, G. Sautermeister, S. Schneider (Eds.), Deutschland nach Hitler. Zukunftspläne im Exil und aus der Besatzungszeit 1939*-1949 (pp. 123-135). Opladen: Westdeutscher Verlag.

Lange-Quassowski, J-B 1979. Neuordnung oder Restauration? Das Demokratiekonzept der amerikanischen Besatzungsmacht und die politische Sozialisation der

Westdeutschen. Wirtschaftsordnung, Schulstruktur, Politische Bildung. Opladen: Westdeutscher Verlag.

Liebner, P 2001. Paul Tillich und der Council for a Democratic Germany (1933-1945). Frankfurt a. Main: Lang.

Lingk, M 1996. Amerikanische Besatzer und deutsche Kirchen. Tübingen: UVT.

Littell, FH 1960. The German phoenix. Men and movements in the Church in Germany. New York: Doubleday.

McClaskey, B 1951. The History of US Policy and Programme in the Field of Religious Affairs under the Office of the US High Commissioner for Germany. Research Project No. 104, February.

Merritt, R 1995. Democracy imposed. US occupation policy and German public, 1945-1949. New Haven: Connecticut: Yale University Press.

Montgomery, JD 1957. Forced to be free. The artificial revolution in Germany and Japan. Chicago: The University of Chicago Press.

NA, RG 260 OMGUS, 12/86-1/24. Box 881, Folder 208.3 Records of the Education and Cultural Relations Division, Hq. Chief: Correspondence and related records (decimal file), 1945-49, Washington DC.

NA, RG 260 OMGUS, 12/229-3/3. Zone handbook southwest through German basic handbook. Box 1298, Washington DC. (April 1944).

Nahr, W-D 1981. Die befohlene Pressefreiheit. Berlin: Wissenschaftlicher Verlag Spiess. 
Olbrich, J 2001. Geschichte der Erwachsenenbildung in Deutschland. Bonn: Bundeszentrale für politische Bildung.

Parsons, T 1993a. Nazis destroy learning, challenging religion. In U Gerhardt, Talcott Parsons on National Socialism, (pp. 81-84). New York: A de Gruyter.

Parsons, T 1993b. The problem of controlled institutional change. In U Gerhardt, Talcott Parsons on National Socialism, (pp. 291-324). New York: A de Gruyter.

Rosenzweig, B 1998. Erziehung zur Demokratie? Amerikanische Besatzungs- und Schulreformpolitik in Deutschland und Japan. Stuttgart: Steiner.

Rupieper, H-J 1993. Die Wurzeln der westdeutschen Nachkriegsdemokratie. Der amerikanische Beitrag 1945-1952. Opladen: Westdeutscher Verlag.

Scheerer, R 1986. Kirchen für den Kalten Krieg. Grundzüge und Hintergründe der usamerikanischen Religions- und Kirchenpolitik im Nachkriegsdeutschland. Köln: Pahl-Rugenstein.

Spotts, F 1976. Kirchen und Politik in Deutschland. Stuttgart: Deutsche Verlagsanstalt.

Springhart, H 2008. Aufbrüche zu neuen Ufern. Der Beitrag von Religion und Kirche für Demokratisierung und Reeducation im Westen Deutschlands nach 1945. Leipzig: Evangelische Verlagsanstalt.

Springhart, H 2007. 'Das es eine Hoffnung gibt für Deutschland...' Religion und Kirchen im Nachkriegsdeutschland als gesellschaftliche Institutionen der Reeducation. In H Braun, U Gerhardt \& E Holtmann (eds.), Die lange Stunde Null. Gelenkter sozialer Wandel in Westdeutschland nach 1945, (pp. 91-117). Baden-Baden: Nomos.

Supreme Headquarters, Allied Expeditionary Force. Handbook for Military Government in Germany prior to Defeat or Surrender, December 1944.

Supreme Headquarters, Allied Forces G-5 Division. Technical Manual for Education and Religious Affairs, chap. 11, Military Government Germany, The Religious Press. February 1945.

SWNCC (State-War-Navy Coordinating Committee) 1950. Long-Range Policy Statement for German Re-education. In US Department of State, Germany 1947-1949: The Story in Documents, (pp. 541-542). Directive 269/5, Publication 3556. Washington DC: US Department of State.

Tent, JF 1982. Mission on the Rhine. Reeducation and Denazification in AmericanOccupied Germany. Chicago/London: University of Chicago Press.

Tillich, P 1973. An meine deutschen Freunde. Die politischen Reden Paul Tillichs während des Zweiten Weltkriegs über die 'Stimme Amerikas', GWE III. Stuttgart: Evangelisches Verlagswerk.

Tillich, P 1972. Es geht um die Methode. Antwort Paul Tillichs an die Kritiker im 'Aufbau'. In P Tillich (ed.), Impressionen und Reflexionen. Ein Lebensbild in Aufsätzen, Reden und Stellungnahmen GW 13. Stuttgart: Evangelisches Verlagswerk.

Treidel, RJ 2001. Evangelische Akademien im Nachkriegsdeutschland. Gesellschaftspolitisches Engagement in kirchlicher Öffentlichkeitsverantwortung. Stuttgart: Kohlhammer.

Vollnhals, C 1989. Entnazifizierung und Selbstreinigung im Urteil der evangelischen Kirche. München: Kaiser.

Welker, M 1995. Kirche im Pluralismus. Gütersloh: Kaiser. 
Weisz, C (ed.)1994. OMGUS- Handbuch. Die amerikanische Militärregierung in Deutschland 1945-1949. München: Oldenbourg.

Weyerer, G 2001. Liebesgaben aus Übersee. Die CARE-Pakete. In D Junker (ed.), Die USA und Deutschland im Zeitalter des Kalten Krieges 1945-1990, Vol. 1, 1945-1968 (pp. 795-802). München: DVA.

Winkler, HA 2004. Der lange Weg nach Westen, Vol. 2. Deutsche Geschichte 1933-1990. Bonn: Bundeszentrale für politische Bildung.

Wü, D 1/205, 20. Memorandum: Der gegenwärtige Stand der Erziehung in Deutschland.

Wü, D1/208, EE Turner 1945. Ein Abschiedswort an meine Freunde in der Bekennenden Kirche, 20.12.1945.

Wü, D1/272, Maier, WA 1947. Bericht und Anregungen über Religiöse Rundfunkübertragungen in Deutschland (Amerikanische Zone), 14.10.1947.

Zepp, M 2007. Redefining Germany. Reeducation, Staatsbürgerschaft und Frauenpolitik im US-amerikanisch besetzten Nachkriegsdeutschland. Göttingen: V\&R Unipress.

Zink, H 1947. American military government in Germany. New York: Macmillan. 